\section{OPEN ACCESS}

Edited by:

Xihong Zhao,

Wuhan Institute of Technology, China

Reviewed by:

Yuting Tian

Fujian Agriculture and Forestry

University, China

Ying Mu,

University of Tennessee Health

Science Center (UTHSC),

United States

Wensen Jiang,

Cedars Sinai Medical Center,

United States

*Correspondence:

Xiangjun Gong

msxjgong@scut.edu.cn

Junyan Liu

jliu81@uthsc.edu

${ }^{\dagger}$ These authors have contributed equally to this work

Specialty section: This article was submitted to

Food Microbiology,

a section of the journal

Frontiers in Microbiology

Received: 08 April 2020

Accepted: 15 July 2020

Published: 21 August 2020

Citation:

Li Y, Huang T, Bai C, Fu J,

Chen L, Liang Y, Wang K, Liu J, Gong $X$ and Liu J (2020) Reduction,

Prevention, and Control of Salmonella enterica Viable but Non-culturable

Cells in Flour Food.

Front. Microbiol. 11:1859.

doi: 10.3389/fmich.2020.01859

\title{
Reduction, Prevention, and Control of Salmonella enterica Viable but Non-culturable Cells in Flour Food
}

Yanmei Li't, Tengyi Huang ${ }^{2 t}$, Caiying Bai ${ }^{3}$, Jie Fu' ${ }^{1}$, Ling Chen ${ }^{4,5}$, Yi Liang ${ }^{6}$, Kan Wang ${ }^{7}$, Jun Liu ${ }^{8}$, Xiangjun Gong ${ }^{8 *}$ and Junyan Liu ${ }^{9 *}$
${ }^{1}$ Department of Haematology, Guangzhou Women and Children's Medical Center, Guangzhou Medical University, Guangzhou, China, ${ }^{2}$ Department of Laboratory Medicine, The Second Affiliated Hospital of Shantou University Medical College, Shantou, China, ${ }^{3}$ Guangdong Women and Children Hospital, Guangzhou, China, ${ }^{4}$ Guangdong Province Key Laboratory for Green Processing of Natural Products and Product Safety, School of Food Science and Engineering, South China University of Technology, Guangzhou, China, ${ }^{5}$ Overseas Expertise Introduction Center for Discipline Innovation of Food Nutrition and Human Health (111 Center), Guangzhou, China, ${ }^{6}$ Guangdong Zhongqing Font Biochemical Science and Technology Co., Ltd., Maoming, China, ${ }^{7}$ Research Center of Translational Medicine, The Second Affiliated Hospital of Shantou University Medical College, Shantou, China, ${ }^{8}$ School of Materials Science and Engineering, South China University of Technology, Guangzhou, China, ${ }^{9}$ Department of Civil and Environmental Engineering, University of Maryland, College Park, MD, United States

The processing and storage conditions of flour food inevitably pose environmental stress, which promote bacteria to enter a viable but non-culturable (VBNC) state. The existence of VBNC cells causes false-negative detection in traditional culture-based detection methods, resulting in food quality and safety issues. This study aimed at investigating the influence factors including nutrition, acid, salt, and temperature for the entry into a VBNC state of Salmonella enterica and an efficient detection method. During induction with multi-stress conditions, nutrition starvation antagonizes with lowlevel acidity. Besides, high-level acidity was considered as an inhibitor for VBNC induction. Four inducers including nutrition starvation, salt stress, low-level acidity, and low temperature were concluded for a VBNC state. In addition, the keynote conditions for S. enterica entering a VBNC state included (i) nutrient-rich acidic environment, (ii) oligotrophic low-acidity environment, and (iii) oligotrophic refrigerated environment. Based on the keynote conditions, the environmental conditions of high acidity $(1.0 \%$ $\mathrm{v} / \mathrm{v}$ acetate) with low temperature $\left(-20^{\circ} \mathrm{C}\right)$ could successfully eliminate the formation of $S$. enterica VBNC cells in flour food. In addition, combining with propidium monoazide pretreatment, PCR technology was applied to detect S. enterica VBNC cells. The sensitivity of the PMA-PCR technology was $10^{5} \mathrm{CFU} / \mathrm{ml}$ in an artificially simulated food system. The results derived from this study might aid in the detection and control of VBNC state $S$. enterica in flour food products.

Keywords: Salmonella enterica, propidium monoazide, viable but non-culturable, environmental stress conditions, food system 


\section{HIGHLIGHTS}

- PMA-PCR technology was applied to detect Salmonella enterica viable but non-culturable (VBNC) cells with a sensitivity of $10^{5} \mathrm{CFU} / \mathrm{ml}$.

- The keynote conditions for S. enterica entering a VBNC state include nutrient-rich acidic environment, oligotrophic low-acidity environment, and oligotrophic refrigerated environment.

- A high acidity $(1.0 \% \mathrm{v} / \mathrm{v}$ acetate) plus frozen temperature $\left(-20^{\circ} \mathrm{C}\right)$ environmental condition could successfully inhibit the formation of $S$. enterica VBNC cells and eliminate it in flour food.

\section{INTRODUCTION}

In the food industry, flour food is frequently contaminated by foodborne bacteria including Staphylococcus aureus, Salmonella enterica, and Escherichia coli $\mathrm{O} 157$ (Kirk et al., 2015; Lin et al., 2017; Miao et al., 2017c; Zhao et al., 2018a,b; Liu et al., 2019; Sharma et al., 2019). Foodborne S. enterica is a typical zoonotic pathogen with multiple toxic effects including invasiveness, endotoxin, and enterotoxin (Eng et al., 2015; Bao et al., 2017b,c; Xie et al., 2017a; Jia et al., 2018; Wen et al., 2020). Recently, studies had reported that $S$. enterica can form viable but nonculturable (VBNC) cells under certain environmental stresses (e.g., low temperature, salt stress, nutrient starvation) (Roszak et al., 1984; Chmielewski and Frank, 1995; Gupte et al., 2003; Kusumoto et al., 2012; Zeng et al., 2013; Morishige et al., 2017; Highmore et al., 2018). In addition to the natural environment, the generation of an S. enterica VBNC state also occurred during chlorination of wastewater or food (Oliver et al., 2005; Highmore et al., 2018). In the food industrial environment, the common non-ionic detergents and sanitizers were found to induce an $S$. enterica VBNC state formation (Morishige et al., 2013; Purevdorj-Gage et al., 2018; Robben et al., 2018). Besides, oxidation stress induced by non-thermal sterilization technologies had been confirmed to have a positive relationship with generation of VBNC S. typhimurium cells (Liao et al., 2018). Moreover, storage and complex components of food inevitably cause multistress conditions including high acidity and salt, nutrient starvation, and low temperature (Xu et al., 2011b; Liu et al., 2018a,b). Therefore, S. enterica VBNC cells could exist in the food industry and processing plants, and even food production. As the detection of foodborne pathogens in foods was based on colony-counting method, bacterial VBNC cells cause false-negative results and remain in food (Bao et al., 2017a; Xie et al., 2017b; Xu et al., 2018). Although VBNC cells have low activity, some frozen food has a long shelf life so that VBNC cells have enough time to metabolize causing food spoilage, which poses a certain safety hazard to human health (Fakruddin et al., 2013; Zeng et al., 2013; Highmore et al., 2018).

Although S. enterica VBNC cells could be resuscitated by favorable conditions, the recovery of VBNC cells from different environmental stresses requires different methods, such as temperature upshift (Gupte et al., 2003; Zeng et al., 2013), catalase
(Zeng et al., 2013 Morishige et al., 2017), Tween 80 (Zeng et al., 2013), and nutrients (Roszak et al., 1984; Morishige et al., 2013). Therefore, the detection of $S$. enterica VBNC cells by resuscitation is infeasible. In recent years, combining propidium monoazide (PMA) treatment with nucleic acid amplification technologies has shown to be capable of rapidly detecting VBNC bacteria (Wang et al., 2011; Xu et al., 2011a,b, 2012a,b, 2016a,b; You et al., 2012; Liu et al., 2015, 2017; Jiang et al., 2016; Lin et al., 2016; Miao et al., 2016, 2017a,b, 2018; Ma et al., 2017; Wang et al., 2019).

In this study, the induction and control of VBNC state formation focused on specific environmental conditions were investigated (Zhang et al., 2013; Miao et al., 2017c; Xu et al., 2011a,c). Also, we applied the PMA-PCR method to detect the targeted gene invA of S. enterica VBNC cells in a food system (Xu et al., 2007, 2008a,b, 2009, 2010).

\section{MATERIALS AND METHODS}

\section{Bacteria Strains and DNA Extraction}

The bacterial strains (Table 1) were grown in tryptic soy broth (TSB, Huankai Microbial, China) cultures at $37^{\circ} \mathrm{C}$ at $200 \mathrm{rpm}$ for $24 \mathrm{~h}$ until further use. Then $1.5-2 \mathrm{ml}$ of culture was used in DNA extraction by a DNA extraction kit (Dongsheng Biotech, Guangzhou) following the manufacturer's instructions. Nano Drop 2000 (Thermo Fisher Scientific Inc., Waltham, MA, United States) was applied to measure the concentration of the extracted DNA for controlling the ratio value of $\mathrm{OD}_{260} / \mathrm{OD}_{280}$ from 1.8 to 2.0. All of the DNA samples were stored at $-20^{\circ} \mathrm{C}$ until further use.

\section{Induction of S. enterica VBNC Status}

According to the food environmental condition, a total of three factors were selected as a single variable including nutrient, salt, and acid (Table 3). The designed orthogonal array was divided into 16 groups (Table 4), and the trend on the number of cultivable bacteria is used as an index to investigate the effect of external environmental pressure on the formation of S. enterica VBNC. The S. enterica VBNC status was induced by the 16 groups of conditions at low temperature $\left(4^{\circ}\right.$ or $\left.-20^{\circ} \mathrm{C}\right)$. The overnight bacterial culture $\left(\sim 10^{8} \mathrm{CFU} / \mathrm{ml}\right)$ was washed three times and resuspended by sterile saline. Besides, aliquots of these bacterial suspensions were separated into $1.5 \mathrm{ml}$ tubes $(\sim 20)$

TABLE 1 | Bacteria used in the study.

\begin{tabular}{lc}
\hline Species & Source \\
\hline Escherichia coli O157:H7 ATCC47853 & ATCC \\
Escherichia coli O157:H7 ATCC25922 & ATCC \\
Salmonella enterica ATCC14028 & ATCC \\
Salmonella enterica ATCC29629 & ATCC \\
Pseudomonas aeruginosa ATCC27853 & ATCC \\
Staphylococcus aureus 10071 & Laboratory strain \\
Listeria monocytogenes ATCC19115 & ATCC \\
L. monocytogenes ATCC19116 & ATCC \\
Lactobacillus casei & Laboratory strain
\end{tabular}


TABLE 2 | Primer sequences of the target genes.

\begin{tabular}{llc}
\hline Primer & Sequence $\left(\mathbf{5}^{\prime} \mathbf{-} \mathbf{3}^{\prime}\right)$ & Length \\
\hline invA-Ft & CACAAAGATGATAATGATGCCAATACTGGAAAGGGAAAGCC & 41 \\
invA-Bt & CCGTAGTAATAGTAGAAACACGACAGAGCGGAGGATAAA & 39 \\
invA-IF & TCATCGCACCGTCAAA & 16 \\
invA-IB & TGGCGGTATTCGGTGGG & 18
\end{tabular}

TABLE 3 | External environmental factors during induction of the VBNC state of Salmonella.

\begin{tabular}{lcc}
\hline TSB (\%) & $\mathbf{N a C l}(\%)$ & Acetate (\%) \\
\hline 0 & 0.9 & 0 \\
25 & 10 & 0.3 \\
50 & 20 & 0.7 \\
100 & 30 & 1 \\
\hline
\end{tabular}

to avoid the effect of repeated freeze-thaw. The viability of bacterial cells was characterized by the colony counting method, and the VBNC cells were determined by LIVE/DEAD BacLight ${ }^{\circledR}$ kit (Thermo Fisher Scientific, United States) with fluorescence microscope after the culturable colonies no longer form on an agar medium. The culturable and viable cell enumerations were preformed every 3 days.

\section{PMA-PCR}

The S. enterica-specific gene invA was selected as the target gene, and corresponding primers were designed (Table 2). The selected conserved regions were determined to be highly specific by sequence comparison on the Blast website. Primer Premier 5 was used to design primers for the PCR amplification reaction. All primers were synthesized by Guangzhou Aiji Biotechnology Co., Ltd. The mentioned bacterial DNA extraction was employed as a template for PCR amplification. The PCR assay was performed in a $25 \mu \mathrm{l}$ volume with $1.6 \mu \mathrm{l}$ of detection primer $(50 \mu \mathrm{M})$ and $0.8 \mu \mathrm{l}$ of accelerated primer $(50 \mu \mathrm{M})$. The thermal profile for PCR was $94^{\circ} \mathrm{C}$ for $5 \mathrm{~min}$, followed by the condition for 30 cycles: denaturation of $94^{\circ} \mathrm{C}$ for $30 \mathrm{~s}$, primer annealing at $55^{\circ} \mathrm{C}$ for $30 \mathrm{~s}$, and extension at $72^{\circ} \mathrm{C}$ for $1 \mathrm{~min}$ and a final extension cycle at $72^{\circ} \mathrm{C}$ for $7 \mathrm{~min}$. A negative control was performed using sterile water instead of culture or DNA template. Finally, the specificity and sensitivity of the designed primer was determined by electrophoresis.

\section{PMA-PCR Detection on S. enterica VBNC Cells in a Food System}

Twenty-five grams of crystal cake powder was added to $225 \mathrm{ml}$ of sterile saline and autoclaved. The 1-ml overnight culture $\left(\sim 10^{8} \mathrm{CFU} / \mathrm{ml}\right.$ ) was diluted 10 fold by adding $9 \mathrm{ml}$ of sterile flour solutions to prepare the artificially contaminated food samples with different concentrations $\left(10^{7}-10\right)$. Before the extraction of bacterial DNA, artificially contaminated samples were pretreated according to the following steps: (1) $1 \mathrm{ml}$ of the flour solution was centrifuged for $10 \mathrm{~min}$ at 1,000 rpm to remove the macroparticles, then the supernatant was centrifuged again at $12,000 \mathrm{rpm}$ for $10 \mathrm{~min}$ to collect precipitations. (2) The precipitations were
TABLE 4 | The experimental methods of orthogonal array design of VBNC induction of Salmonella.

\begin{tabular}{lccc}
\hline Group & TSB (\%) & NaCl (\%) & Acetate (\%) \\
\hline 1 & 0 & 0.9 & 0 \\
2 & 25 & 0.9 & 0.3 \\
3 & 50 & 0.9 & 0.7 \\
4 & 100 & 0.9 & 1 \\
5 & 25 & 10 & 0 \\
6 & 0 & 10 & 0.3 \\
7 & 100 & 10 & 0.7 \\
8 & 50 & 10 & 1 \\
9 & 50 & 20 & 0 \\
10 & 100 & 20 & 0.3 \\
11 & 0 & 20 & 0.7 \\
12 & 25 & 20 & 1 \\
13 & 100 & 30 & 0 \\
14 & 50 & 30 & 0.3 \\
15 & 25 & 30 & 0.7 \\
16 & 0 & 30 & 1 \\
\hline
\end{tabular}

resuspended in $500 \mu \mathrm{l}$ of sterile saline and then mixed with $125 \mu \mathrm{l}$ of ethyl acetate for $2 \mathrm{~min}$ to remove impurities such as oil and fat. After centrifugation at $12,000 \mathrm{rpm}$ for $10 \mathrm{~min}$, the precipitations were washed once with $500 \mu \mathrm{l}$ of TE buffer and twice with $500 \mu \mathrm{l}$ of sterile saline.

The range of $S$. enterica VBNC cell concentration was adjusted from 10 to $10^{6}$ cells $/ \mathrm{ml}$. Subsequently, the propidium monoazide (PMA) dye was added to the flour samples until its concentration reached $5 \mu \mathrm{g} / \mathrm{ml}$. After incubation at room temperature for $10 \mathrm{~min}$ in the dark, the samples were exposed to a $650 \mathrm{~W}$ halogen lamp with a distance of $15 \mathrm{~cm}$ for $5 \mathrm{~min}$, which inactivated unbinding PMA molecules rather than PMA-DNA molecules. All the dyeing process was performed in an ice bath to prevent DNA damage. Subsequently, the DNA extraction and PCR detection of PMA-treated cells were performed.

\section{RESULTS}

\section{Induction of S. enterica VBNC State}

The exponential-phase $S$. enterica cells were induced to a VBNC state by low-temperature storage (Figure 1). After 30 days of storage at $4^{\circ}$ or $-20^{\circ} \mathrm{C}$, the culturable number dropped to 0 . As fluorescent green cells could be captured by microscopy, S. enterica was considered to be successfully induced into a VBNC status (Figure 2), with live and dead cells that coexisted.

\section{Effects of Environmental Conditions on S. enterica VBNC State Culturable Number of $S$. enterica Cells}

According to four external environmental factors (nutrient, salinity, acidity, and temperature), the orthogonal array was designed to induce $S$. enterica VBNC cells including 16 groups (Table 4). Non-culturable cells were found in eight groups (groups 3, 4, 6, 8, 11, 12, 15, and 16) after 3 days of induction. 


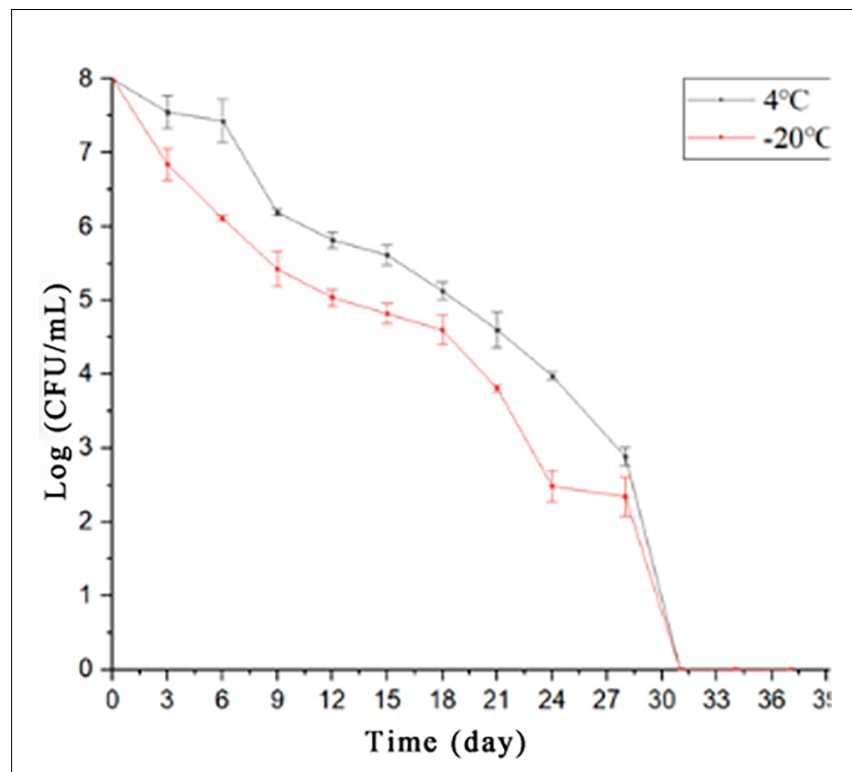

FIGURE 1 | The culturable cells of foodborne Salmonella under low nutrients at $4^{\circ}$ or $-20^{\circ} \mathrm{C}$.

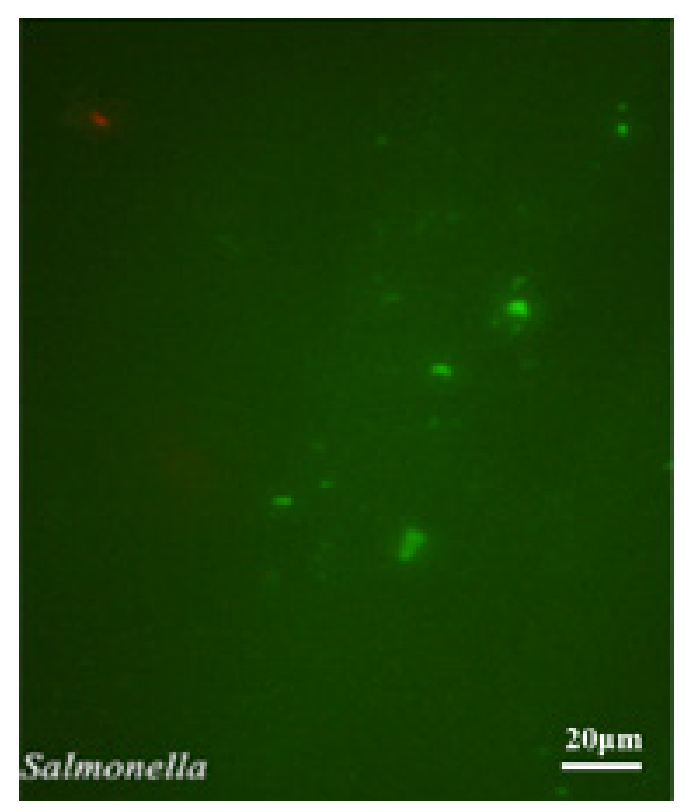

FIGURE 2 | The observation of unculturable Salmonella cells by fluorescence microscope.

Seven groups (groups 3, 4, 8, 11, 12, 15, and 16) had a high concentration $(\geq 0.7 \% \mathrm{v} / \mathrm{v})$ of acetate, indicating that the viability of $S$. enterica might be mainly inhibited by high acidity. When supplied with adequate nutrition, the $S$. enterica cells could survive under acidic stress from $0.7 \% \mathrm{v} / \mathrm{v}$ acetate within 30 days (group 7), suggesting that nutrition may be a stimulated bacterial stress response mechanism to resist acetate. The culturable number in the other groups (groups 1, 7, 9, 10,
13, and 14) showed a decreasing trend to reach 0 (Figure 3). The accurate time required for each protocol to reach a nonculturable cell state at $4^{\circ} \mathrm{C}$ and $-20^{\circ} \mathrm{C}$ differed (Table 5). The cells grown in different concentrations of nutrients (groups 2, $5,7,9,10,13$, and 14) could survive for more than 30 days. However, the result of group 4 showed that under a nutrientrich condition (100\%), high acidic stress (1\% v/v acetate) still inactivated $S$. enterica cells within 3 days of storage, revealing that the effect of acidity on cell viability was stronger than nutrients. Interestingly, in protocols 2 and 5, the trend of culturable cell numbers had a significant difference, as the $S$. enterica remained at cell numbers higher than $10^{4} \mathrm{CFU} / \mathrm{ml}$ at $4^{\circ} \mathrm{C}$ rather than at $-20^{\circ} \mathrm{C}$. This phenomenon demonstrated that freezing conditions $\left(-20^{\circ} \mathrm{C}\right)$ might contribute to inhibit bacterial growth.

In summary, under higher than $0.7 \% \mathrm{v} / \mathrm{v}$ of acetate, the order of environmental conditions in affecting the survival of $S$. enterica was as follows: acidity $>$ nutrients $>$ salt. With the reduction in acidity, the supplement of certain nutrients promoted $S$. enterica to resist environmental stress.

\section{Salmonella enterica VBNC State Formation}

Although $S$. enterica were no longer culturable in eight groups (groups 1, 2, 5, 7, 9, 10, 13, and 14), the viable cells were still captured by fluorescence microscopy (Figure 4). These results demonstrated that VBNC cells were successfully induced by freezing conditions $\left(-20^{\circ} \mathrm{C}\right)$ with long-term storage ( $\sim 30$ days). As none of viable $S$. enterica cells were observed from other groups (groups 3, 4, 6, 8, 11, 12, 15, and 16) in which bacteria lost culturability within a short-term storage ( $\sim 3$ days) (data not shown), the formation of a VBNC state might require $S$. enterica to suffer by long-term induction of sublethal environmental stress and low temperature.

Most non-viable cell groups contained more than $0.7 \%$ $\mathrm{v} / \mathrm{v}$ acetate, indicating that high-level acidity environmental condition induced cell death rather than the formation of a VBNC state, although a previous study had reported that an $S$. enterica VBNC state could be induced by lactic acid or peracetic acid (Purevdorj-Gage et al., 2018). Interestingly, a VBNC state was induced under $0.7 \% \mathrm{v} / \mathrm{v}$ acetate by supplying sufficient nutrients (100\%), suggesting that nutrients were essential for $S$. enterica entering a VBNC state in response to multistress conditions including inorganic salts and weak acid.

As described by Chen et al. (2019) more than 10 or $1 \%$ of $S$. enterica cells were induced into a VBNC state without nutrients at $4^{\circ}$ or $-20^{\circ} \mathrm{C}$, respectively. In our study, S. enterica entered into a VBNC state under starvation condition at $4^{\circ}$ or $-20^{\circ} \mathrm{C}$ (groups $1,2,5,7,9,10,13$, and 14). Other previous studies had described similar results and showed that temperature upshift and growth factors (catalase and Tween 20) were required for resuscitation (Gupte et al., 2003; Zeng et al., 2013). Moreover, groups 2 and 5 showed that a decreasing temperature could accelerate the reduction of culturable cells and the generation of VBNC cells, which revealed that the decrease in temperature was one of the essential inducers. Besides, consistent with previous report, our results showed that the generation of $S$. enterica VBNC cells could be induced by salt stress with different concentrations, indicating 


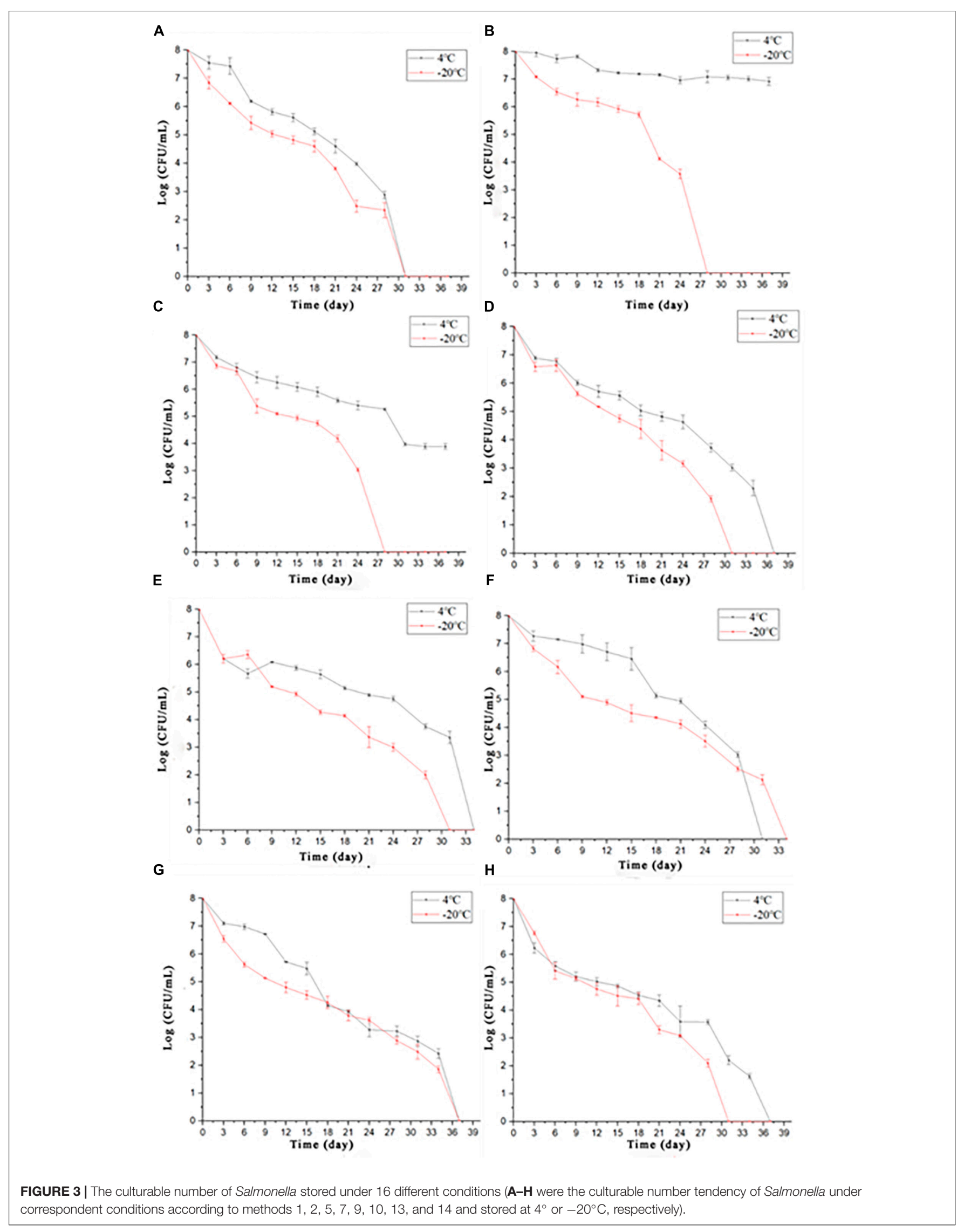


TABLE 5 | The time of culturable number of Salmonella decreased to 0 stored at different protocols.

\begin{tabular}{lccccc}
\hline Group & $\mathbf{4}^{\circ} \mathbf{C}$ & $\mathbf{- 2 0 ^ { \circ } \mathbf { C }}$ & Group & $\mathbf{4}^{\circ} \mathbf{C}$ & $\mathbf{2 0}^{\circ} \mathbf{C}$ \\
\hline 1 & $31 \mathrm{~d}$ & $31 \mathrm{~d}$ & 9 & $34 \mathrm{~d}$ & $31 \mathrm{~d}$ \\
2 & + & $28 \mathrm{~d}$ & 10 & $31 \mathrm{~d}$ & $34 \mathrm{~d}$ \\
3 & $/$ & $/$ & 11 & $/$ & $/$ \\
4 & $/$ & $/$ & 12 & $/$ & $/$ \\
5 & + & $28 \mathrm{~d}$ & 13 & $37 \mathrm{~d}$ & $37 \mathrm{~d}$ \\
6 & $/$ & $/$ & 14 & $37 \mathrm{~d}$ & $31 \mathrm{~d}$ \\
7 & $37 \mathrm{~d}$ & $31 \mathrm{~d}$ & 15 & $/$ & $/$ \\
8 & $/$ & $/$ & 16 & $/$ & $/$
\end{tabular}

"+" represents cultivable; "" represents non-culturable within 3 days.

that salt stress was another inducer for a VBNC state formation (Asakura et al., 2002).

Together, four inducers including nutrition starvation, salt stress, low-level acidity, and low temperature were concluded for VBNC state induction. However, during induction with multistress conditions, nutrition starvation antagonizes with low-level acidity. Besides, high-level acidity was considered as an inhibitor for VBNC induction. Therefore, the keynote environmental factors of VBNC state induction were concluded to be: (i) nutrient-rich acidic environment, (ii) oligotrophic low-acidity environment, and (iii) oligotrophic refrigerated environment.

\section{Effects of Keynote Environmental Factors on Salmonella VBNC State Formation Acidity}

Acetate had been utilized as an antimicrobial chemical for many years in food production. As previously described by Liao et al. (2003) exposing Salmonella cells to 0.7 or $1.0 \%$ acetic acid for 7 min usually caused $90 \%$ cells with inactivation and $99 \%$ of culturable cells with injury. In agreement with a related study, cell viability was evaluated based on cultivability, neglecting the generation of Salmonella VBNC cells induced by acetate in vitro (Alvarez-Ordonez et al., 2010). Encountering
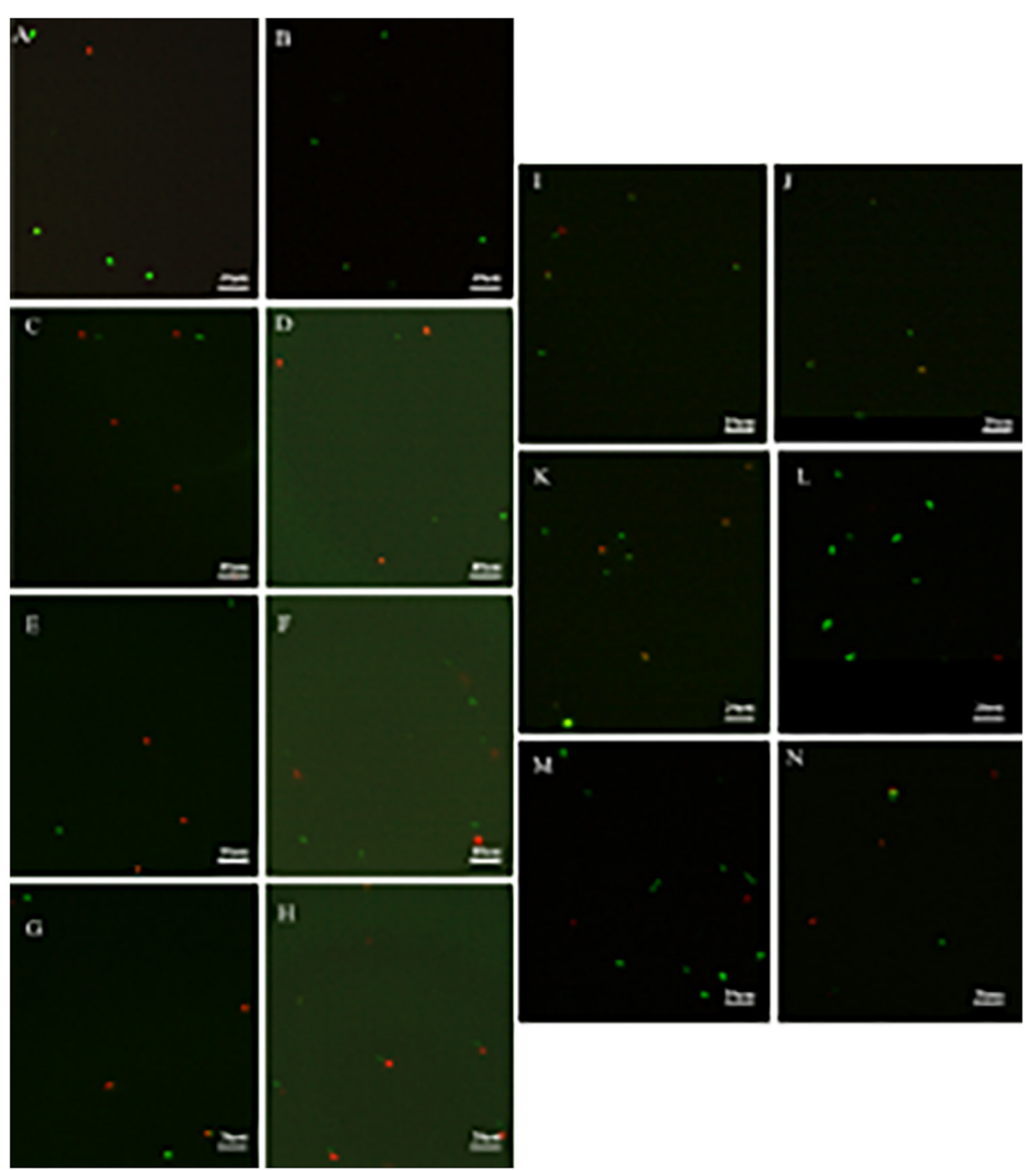

s
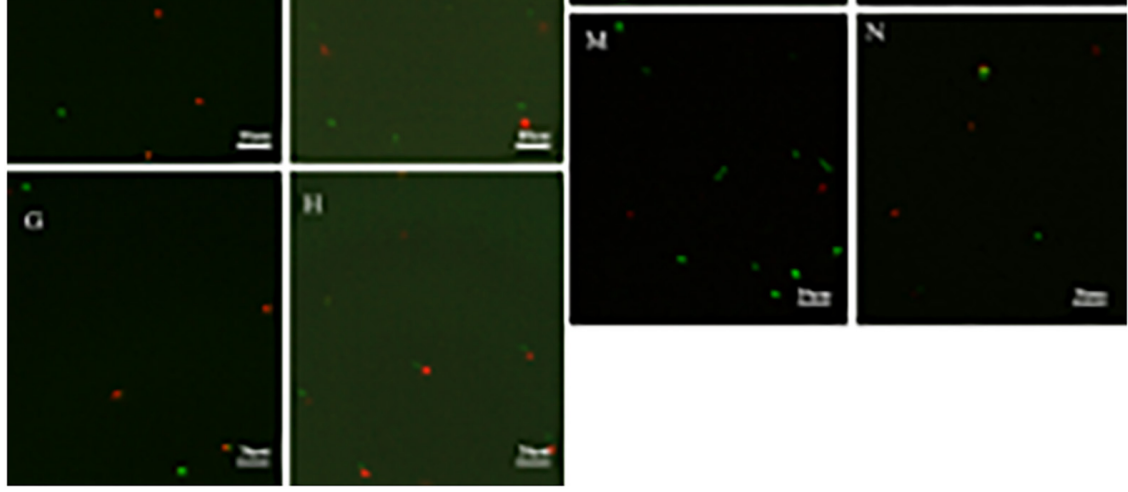

FIGURE 4 | The viability of non-culturable Salmonella stored at different conditions by fluorescent observation (A,B: group 1; C: group 2; D: group 5; E,F: group 7; G,H: group 9; I,J: group 10; K,L: group 13; M,N: group 14). 
organic acid stress causing the acidification of the cytoplasm and the accumulation of intracellular anion, the available energy is required for $S$. enterica to efflux protons $\left(\mathrm{H}^{+}\right)$by active transport maintaining intracellular $\mathrm{pH}$ homeostasis (Mani-López et al., 2012). Therefore, the effect of acidity $(0.7$ or $1.0 \% \mathrm{v} / \mathrm{v})$ on the formation of an $S$. enterica VBNC state in flour food was investigated with different nutritional concentrations at low temperature $\left(4^{\circ}\right.$ or $\left.-20^{\circ} \mathrm{C}\right)$.

Under oligotrophic conditions, $S$. enterica could not be cultured after 3 days of storage at low temperature $\left(4^{\circ}\right.$ and $-20^{\circ} \mathrm{C}$ ) by adding 0.7 or $1.0 \% \mathrm{v} / \mathrm{v}$ acetic acid (Table 6 ). The bacterial activity test results showed that only dead cells were observed, indicating that S. enterica was unable to enter into a VBNC state. When supplied with sufficient nutrients $(\geq 50 \%)$, the culturable cells still existed under $0.7 \% \mathrm{v} / \mathrm{v}$ acetic acid after 3 days of storage, indicating that acid tolerance of $S$. enterica was improved by available nutrients, which might ultimately lead to generation of VBNC cells. However, when the concentration of acetate reached $1.0 \% \mathrm{v} / \mathrm{v}$, no culturable cells could be found after 3 days of storage, whether provided with nutrients or not. As expected, the activity test results showed that all the bacterial cells were dead, indicating that the formation of a VBNC state of S. enterica could be controlled by adding $1.0 \% \mathrm{v} / \mathrm{v}$ acetate, even when supplied with rich nutrients. Interestingly, only group 7 had showed that all the bacteria were inviable with decreasing temperature under high-level acidity stress $(1.0 \% \mathrm{v} / \mathrm{v}$ acetate). These results were consistent with those previously described by Alvarez-Ordonez et al. (2010), who measured the organic acid tolerance of S. typhimurium at different growth temperatures and found that the reduction of low temperatures markedly decreased the acid resistance and increased the growth $\mathrm{pH}$ boundary of S. typhimurium. In summary, during the processing of flour foods, $1.0 \% \mathrm{v} / \mathrm{v}$ acetic acid could be used to clean the processing equipment, which can effectively eliminate the pollution of S. enterica and its VBNC cells.

\section{Nutrients}

Recently, Pu et al. (2019) proposed that protein aggresome is an important indicator of the E. coli VBNC state, which was promoted by nutrient starvation, but stress removal will facilitate the disaggregation of the proteins by the DnaK-ClpB cochaperone system ( $\mathrm{Pu}$ et al., 2019). Although nutrients also play an important role in the formation of the S. enterica VBNC state, the reduction of nutrients may be a potential method to inhibit S. enterica VBNC cell formation. Under high salt and low acidity, S. enterica cells were still culturable with an oligotrophic condition after 3 days of storage (Table 7), which suggested that only an oligotrophic condition was incapable of inhibiting the formation of VBNC cells. Therefore, it is essential to combine oligotrophic condition with other environmental stress (e.g., high acidity) to prevent $S$. enterica from entering the state of VBNC.

\section{Control and Reduction of S. enterica VBNC Cells in Flour Food}

In order to confirm the inhibitory effect of the above keynote conditions on Salmonella VBNC formation in food samples, we selected crystal cake powders as a sole source of nutrients
TABLE 6 | Inhibition of acidity in the formation of VBNC state of Salmonella.

\begin{tabular}{|c|c|c|c|c|c|c|c|}
\hline \multirow[t]{2}{*}{ Group } & \multirow[t]{2}{*}{ TSB (\%) } & \multirow[t]{2}{*}{$\mathrm{NaCl}(\%)$} & \multirow[t]{2}{*}{ Acetate (\%) } & \multicolumn{2}{|c|}{ Cultivability } & \multicolumn{2}{|c|}{ Viability } \\
\hline & & & & $4^{\circ} \mathrm{C}$ & $-20^{\circ} \mathrm{C}$ & $4^{\circ} \mathrm{C}$ & $-20^{\circ} \mathrm{C}$ \\
\hline 1 & 0 & 0.9 & 0.7 & I & / & - & - \\
\hline 2 & & & 1.0 & / & / & - & - \\
\hline 3 & 25 & 0.9 & 0.7 & / & / & - & - \\
\hline 4 & & & 1.0 & / & / & - & - \\
\hline 5 & 25 & 10 & 0.7 & / & I & - & - \\
\hline 6 & & & 1.0 & / & I & - & - \\
\hline 7 & 100 & 10 & 1.0 & + & / & ND & - \\
\hline 8 & 50 & 20 & 0.7 & + & + & ND & ND \\
\hline 9 & & & 1.0 & / & / & - & - \\
\hline 10 & 100 & 20 & 0.7 & + & + & ND & ND \\
\hline 11 & & & 1.0 & l & / & - & - \\
\hline 12 & 100 & 30 & 0.7 & + & + & ND & ND \\
\hline 13 & & & 1.0 & I & / & - & - \\
\hline 14 & 50 & 30 & 0.7 & + & + & ND & ND \\
\hline 15 & & & 1.0 & / & / & - & - \\
\hline
\end{tabular}

"+" represents culturable; "/" represents non-culturable; "-" represents inactivation; "ND" represents non-detection.

TABLE 7 | Inhibition of nutritional status in the formation of VBNC state of Salmonella.

\begin{tabular}{|c|c|c|c|c|c|c|c|}
\hline \multirow[t]{2}{*}{ Group } & \multirow[t]{2}{*}{ TSB (\%) } & \multirow[t]{2}{*}{$\mathrm{NaCl}(\%)$} & \multirow[t]{2}{*}{ Acetate (\%) } & \multicolumn{2}{|c|}{ Cultivability } & \multicolumn{2}{|c|}{ Viability } \\
\hline & & & & $4^{\circ} \mathrm{C}$ & $-20^{\circ} \mathrm{C}$ & $4^{\circ} \mathrm{C}$ & $-20^{\circ} \mathrm{C}$ \\
\hline 1 & 0 & 20 & 0 & + & + & ND & ND \\
\hline 2 & 25 & & & + & + & ND & ND \\
\hline 3 & 0 & 20 & 0.3 & + & + & ND & ND \\
\hline 4 & 25 & & & + & + & ND & ND \\
\hline 5 & 0 & 30 & 0 & + & + & ND & ND \\
\hline 6 & 25 & & & + & + & ND & ND \\
\hline 7 & 0 & 30 & 0.3 & + & + & ND & ND \\
\hline 8 & 25 & & & + & + & ND & ND \\
\hline
\end{tabular}

"+" represents culturable; "ND" represents non-detection.

instead of TSB to simulate the flour food environment. The keynote conditions used for investigation was high acidity (1.0\% $\mathrm{v} / \mathrm{v}$ acetate) combined with different concentrations $(25,50$, and $100 \%$ ) of nutrients. After 3 days of storage, the culturable number and viability of $S$. enterica in different conditions are shown in Figures 5, 6. Consistent with the results from non-food systems, only dead bacterial cells could be found in simulated food systems after 3 days of storage at $-20^{\circ} \mathrm{C}$, whether they were provided with nutrients or not (Figure 6). On the contrary, Salmonella could still survive after 3 days of storage at $4^{\circ} \mathrm{C}$ via a supplement of sufficient nutrients (100\%) (Figure 6). Although the number of survival of $S$. enterica cells was significantly reduced, there is a possibility of culturable cells entering the VBNC state (Figure 5). Therefore, the best control conditions for the formation of VBNC status of $S$. enterica in flour food is to add $1.0 \% \mathrm{v} / \mathrm{v}$ acetic acid combined with storage at $-20^{\circ} \mathrm{C}$. 


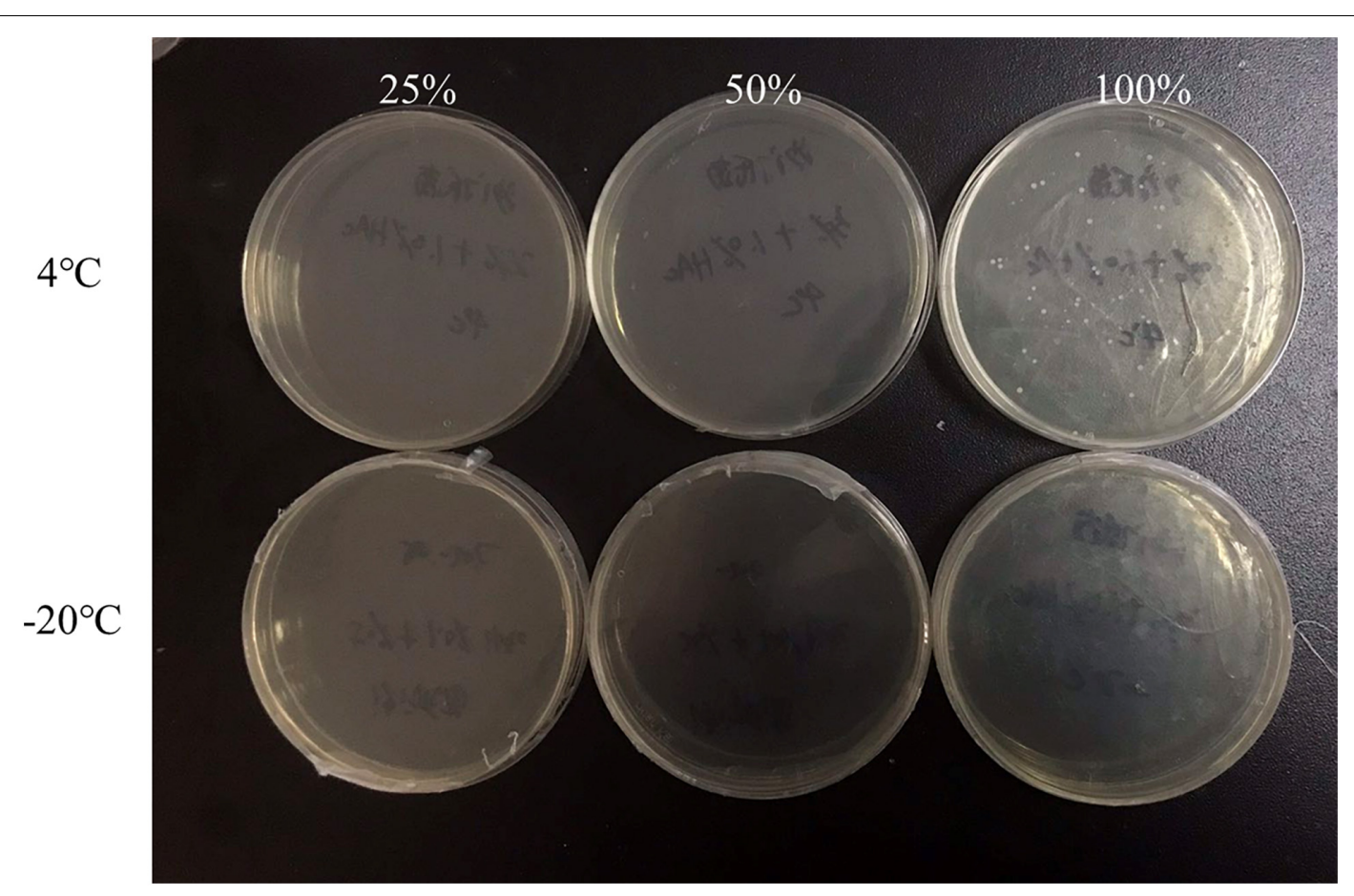

FIGURE 5 | The culturable number of Salmonella inoculated in the 1.0\% (v/v) acetate medium containing 100, 50, and 25\% nutrients at low temperature for 3 days.

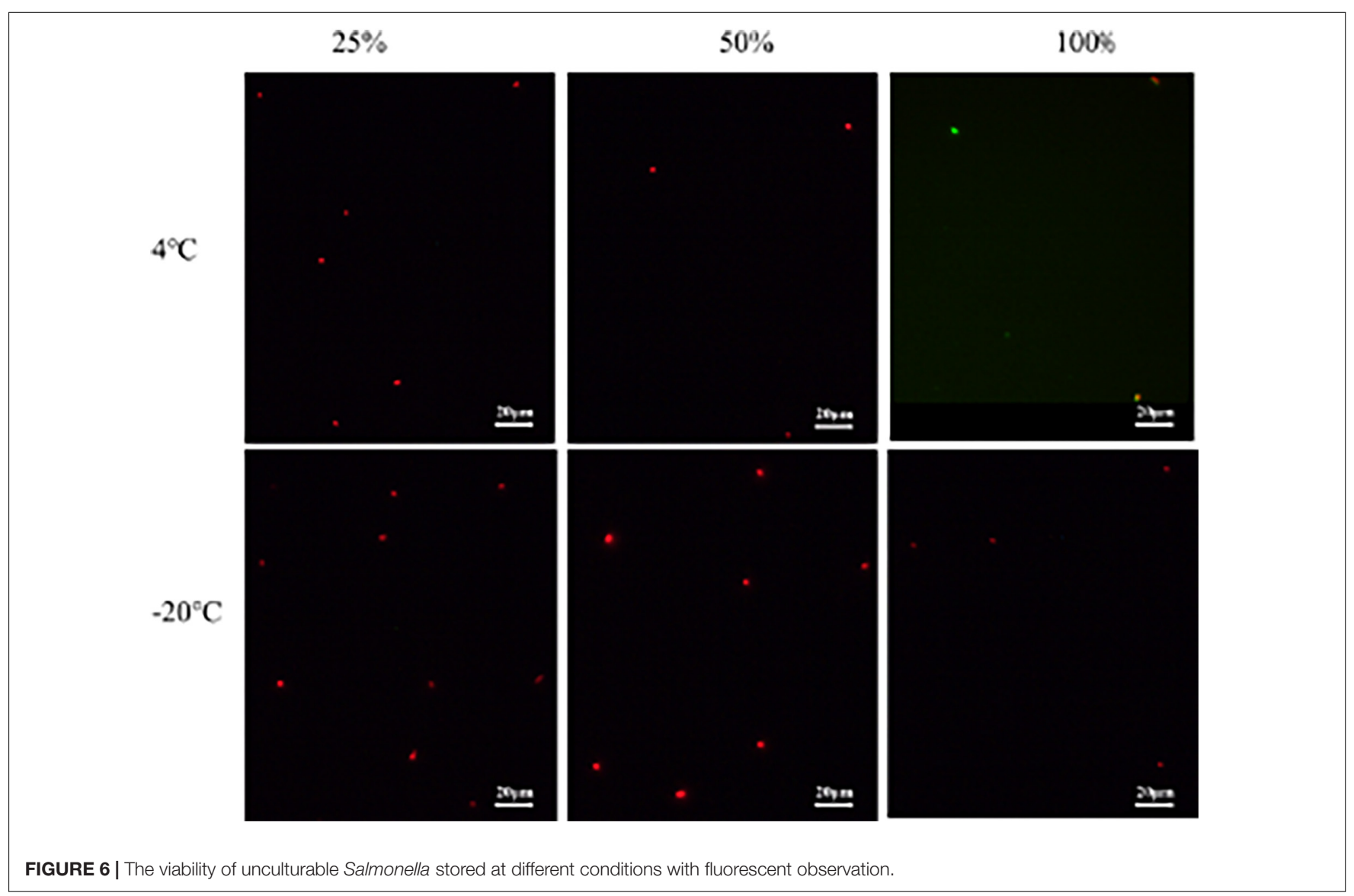


Foodborne pathogenic and spoilage bacteria had been previously shown to enter into a VBNC state in a food system under a freezing environment. Therefore, the results of this study might provide a theoretical basis for the control and reduction of foodborne bacterial VBNC cells.

\section{PMA-PCR Detection on VBNC Cells}

In order to eliminate the interference of dead bacterial DNA, samples were subjected to PMA treatment before PCR amplification. The detection limit of $S$. enterica using the constructed PMA-PCR technology to detect the VBNC status in the crystal cake food system is $10^{5} \mathrm{CFU} / \mathrm{ml}$, which is consistent with the PMA-PCR results in the pure induction system (data not shown). Compared to the detection limit of PCR for culturable S. enterica in food systems, the detection limit of PMA-PCR has no significant changes, suggesting that the PCR method by the PMA dye is non-effective. Therefore, the PMA-PCR method can be better applied to detect viable bacteria (culturable and nonculturable) in a food sample, preventing false-negative detection of a culture-based method on VBNC cells.

\section{CONCLUSION}

In this study, the influence factors including nutrition, acid, salt, and temperature for the entry into a VBNC state of S. enterica and an efficient detection method were investigated. The order of environmental conditions in effecting the cultivability of S. enterica was as follows: acidity $>$ nutrients $>$ salt. Four inducers for the VBNC state including nutrition starvation, salt stress, low-level acidity, and low temperature were concluded. However, during induction with multistress conditions, nutrition starvation antagonizes with low-level acidity. Besides, highlevel acidity was considered as an inhibitor for a VBNC state

\section{REFERENCES}

Alvarez-Ordonez, A., Fernandez, A., Bernardo, A., and Lopez, M. (2010). Acid tolerance in Salmonella typhimurium induced by culturing in the presence of organic acids at different growth temperatures. Food Microbiol. 27, 44-49. doi: 10.1016/j.fm.2009.07.015

Asakura, H., Makino, S., Takagi, T., Kuri, A., Kurazono, T., Watarai, M., et al. (2002). Passage in mice causes a change in the ability of Salmonella enterica serovar oranienburg to survive $\mathrm{NaCl}$ osmotic stress: resuscitation from the viable but non-culturable state. FEMS Microbiol. Lett. 212, 87-93. doi: 10.1111/ j.1574-6968.2002.tb11249.x

Bao, X., Jia, X., Chen, L., Peters, B. M., Lin, C., Chen, D., et al. (2017a). Effect of Polymyxin resistance (pmr) on biofilm formation of Cronobacter sakazakii. Microb. Pathog. 106, 16-19. doi: 10.1016/j.micpath.2016.12.012

Bao, X., Yang, L., Chen, L., Li, B., Lin, L., Li, Y., et al. (2017b). Analysis on pathogenic and virulent characteristics of the Cronobacter sakazakii strain BAA- 894 by whole genome sequencing and its demonstration in basic biology science. Microb. Pathog. 109, 280-286. doi: 10.1016/j.micpath.2017.05.030

Bao, X., Yang, L., Chen, L., Li, B., Lin, L., Li, Y., et al. (2017c). Virulent and pathogenic features on the Cronobacter sakazakii polymyxin resistant pmr mutant strain s-3. microbial pathogenesis. Microb. Pathog. 110, 359-364. doi: 10.1016/j.micpath.2017.07.022

Chen, H., Zhong, C., Zhang, T., Shu, M., Lin, L., Luo, Q., et al. (2019). Rapid and sensitive detection of viable but non-culturable Salmonella induced by low temperature from chicken using EMA-Rti-LAMP combined with BCAC. Food Anal. Methods. 13, 313-324. doi: 10.1007/s12161-019-01655-9 formation. Therefore, the keynote conditions for S. enterica entering the VBNC state were concluded as (i) nutrient-rich acidic environment, (ii) oligotrophic low-acidity environment, and (iii) oligotrophic refrigerated environment. Thus, using an environment condition of high acidity $(1.0 \% \mathrm{v} / \mathrm{v}$ acetate $)$ with low temperature $\left(-20^{\circ} \mathrm{C}\right)$, the formation of $S$. enterica VBNC state was eliminated in flour food. Combined with PMA pretreatment, the PCR technology could be applied to detect viable $S$. enterica cells (culturable and VBNC) removing the interference of dead cells. The detection limit of the PMA-PCR technology was $10^{5} \mathrm{CFU} / \mathrm{ml}$ in an artificially simulated food system. In conclusion, this study identified specific environmental stresses to control, and applied a stable PMA-PCR method to detect, an S. enterica VBNC state, providing a theoretical basis for the control and reduction of foodborne bacterial VBNC cells.

\section{DATA AVAILABILITY STATEMENT}

All datasets presented in this study are included in the article/supplementary material.

\section{AUTHOR CONTRIBUTIONS}

JYL and KW conceived of the study and participated in its design and coordination. JF and TH performed the experimental work. CB and LC analyzed the data. YL and JL prepared and revised this manuscript. All authors reviewed and approved the final manuscript.

\section{FUNDING}

This work was supported by the 111 Project (B17018).

Chmielewski, R. A., and Frank, J. F. (1995). Formation of viable but nonculturable Salmonella during starvation in chemically defined solutions. Lett. Appl. Microbiol. 20, 380-384. doi: 10.1111/j.1472-765x.1995.tb01326.x

Eng, S.-K., Pusparajah, P., Ab Mutalib, N.-S., Ser, H.-L., Chan, K.-G., and Lee, L.-H. (2015). Salmonella: a review on pathogenesis, epidemiology and antibiotic resistance. Front. Life Sci. 8:284-293. doi: 10.1080/21553769.2015.105 1243

Fakruddin, M., Mannan, K. S., and Andrews, S. (2013). Viable but nonculturable bacteria: food safety and public health perspective. ISRN Microbiol. 2013:703813.

Gupte, A. R., de Rezende, C. L. E., and Joseph, S. W. (2003). Induction and resuscitation of viable but nonculturable Salmonella enterica serovar typhimurium DT104. Appl. Environ. Microbiol. 69, 6669-6675. doi: 10.1128/ aem.69.11.6669-6675.2003

Highmore, C. J., Warner, J. C., Rothwell, S. D., Wilks, S. A., and Keevil, C. W. (2018). Viable-but-nonculturable listeria monocytogenes and Salmonella enterica serovar thompson induced by chlorine stress remain infectious. mBio 9:e00540-18.

Jia, X., Hua, J., Liu, L., Xu, Z., and Li, Y. (2018). Phenotypic characterization of pathogenic Cronobacter spp. strains. Microb. Pathog. 121, 232-237. doi: 10.1016/j.micpath.2018.05.033

Jiang, X., Dong, D., Bian, L., Zou, D., He, X., Ao, D., et al. (2016). Rapid detection of candida albicans by polymerase spiral reaction assay in clinical blood samples. Front. Microbiol. 7:916. doi: 10.3389/fmicb.2016.00916

Kirk, M. D., Pires, S. M., Black, R. E., Caipo, M., Crump, J. A., Devleesschauwer, B., et al. (2015). World health organization estimates of the global and regional 
disease burden of 22 foodborne bacterial, protozoal, and viral diseases, 2010: a data synthesis. PLoS Med. 12:e1001921. doi: 10.1371/journal.pmed.1001921

Kusumoto, A., Asakura, H., and Kawamoto, K. (2012). General stress sigma factor RpoS influences time required to enter the viable but non-culturable state in Salmonella enterica. Microbiol. Immunol. 56, 228-237. doi: 10.1111/j.13480421.2012.00428.x

Liao, C., Shollenberger, L. M., and Phillips, J. G. (2003). Lethal and sublethal action of acetic acid on Salmonella in vitro and on cut surfaces of apple slices. J. Food Sci. 68, 2793-2798. doi: 10.1111/j.1365-2621.2003.tb05807.x

Liao, H., Zhang, R., Zhong, K., Ma, Y., Nie, X., and Liu, Y. (2018). Induction of a viable but non-culturable state in Salmonella typhimurium is correlated with free radicals generated by thermosonication. Int. J. Food Microbiol. 286, 90-97. doi: 10.1016/j.ijfoodmicro.2018.07.017

Lin, S., Li, L., Li, B., Zhao, X., Lin, C., Deng, Y., et al. (2016). Development and evaluation of quantitative detection of $\mathrm{N}$-epsilon-carboxymethyl-lysine in Staphylococcus aureus biofilm by LC-MS method. Basic Clin. Pharmacol. Toxicol. 118, 33. doi: 10.1007/978-1-4614-3828-1_2

Lin, S., Yang, L., Chen, G., Li, B., Chen, D., Lin, L., et al. (2017). Pathogenic features and characteristics of food borne pathogens biofilm: biomass, viability and matrix. Microb. Pathog. 111, 285-291. doi: 10.1016/j.micpath.2017.08.005

Liu, J., Zhou, R., Li, L., Peters, B. M., Li, B., Lin, C., et al. (2017). Viable but nonculturable state and toxin gene expression of enterohemorrhagic Escherichia coli $\mathrm{O} 157$ under cryopreservation. Res. Microbiol. 168, 188-193. doi: 10.1016/j. resmic.2016.11.002

Liu, L., Lu, Z., Li, L., Li, B., Zhang, X., Zhang, X., et al. (2018a). Physical relation and mechanism of ultrasonic bactericidal activity on pathogenic E. coli with WPI. Microb. Pathog. 117, 73-79. doi: 10.1016/j.micpath.2018.02.007

Liu, L., Xu, R., Li, L., Li, B., Zhang, X., Zhang, X., et al. (2018b). Correlation and in vitro mechanism of bactericidal activity on E. coli with whey protein isolate during ultrasonic treatment. Microb. Pathog. 115, 154-158. doi: 10.1016/ j.micpath.2017.12.062

Liu, L., Ye, C., Soteyome, T., Zhao, X., Xia, J., Xu, W., et al. (2019). Inhibitory effects of two types of food additives on biofilm formation by foodborne pathogens. MicrobiologyOpen 8:e853. doi: 10.1002/mbo3.853

Liu, W., Dong, D., Yang, Z., Zou, D., Chen, Z., Yuan, J., et al. (2015). Polymerase spiral reaction (PSR): a novel isothermal nucleic acid amplification method. Sci. Rep. 5:12723.doi: <PMID<PMID:NOPMID</PMID<

Ma, Y., Deng, Y., Xu, Z., Liu, J., Dong, J., Yin, H., et al. (2017). Development of a propidium monoazide-polymerase chain reaction assay for detection of viable Lactobacillus brevis in beer. Braz. J. Microbiol. 48, 740-746. doi: 10.1016/j.bjm. 2016.11.012

Mani-López, E., García, H. S., and López-Malo, A. (2012). Organic acids as antimicrobials to control Salmonella in meat and poultry products. Food Res. Int. 45, 713-721. doi: 10.1016/j.foodres.2011.04.043

Miao, J., Chen, L., Wang, J., Wang, W., Chen, D., Li, L., et al. (2017a). Current methodologies on genotyping for nosocomial pathogen methicillin-resistant Staphylococcus aureus (MRSA). Microb. Pathog. 107, 17-28. doi: 10.1016/j. micpath.2017.03.010

Miao, J., Chen, L., Wang, J., Wang, W., Chen, D., Li, L., et al. (2017b). Evaluation and application of molecular genotyping on nosocomial pathogen-methicillin-resistant Staphylococcus aureus isolates in Guangzhou representative of Southern China. Microb. Pathog. 107, 397-403. doi: 10.1016/j.micpath.2017.04.016

Miao, J., Liang, Y., Chen, L., Wang, W., Wang, J., Li, B., et al. (2017c). Formation and development of Staphylococcus biofilm: with focus on food safety. J. Food Saf. 37:e12358. doi: 10.1111/jfs.12358

Miao, J., Peters, B. M., Li, L., Li, B., Zhao, X., Xu, Z., et al. (2016). Evaluation of ERIC-PCR for fingerprinting methicillin-resistant Staphylococcus aureus Strains. Basic Clin. Pharmacol. Toxicol. 118:33.

Miao, J., Wang, W., Xu, W., Su, J., Li, L., Li, B., et al. (2018). The fingerprint mapping and genotyping systems application on methicillinresistant Staphylococcus aureus. Microb. Pathog. 125, 246-251. doi: 10.1016/j. micpath.2018.09.031

Morishige, Y., Fujimori, K., and Amano, F. (2013). Differential resuscitative effect of pyruvate and its analogues on VBNC (viable but non-culturable) Salmonella. Microbes Environ. 28, 180-186. doi: 10.1264/jsme2.me12174

Morishige, Y., Koike, A., Tamura-Ueyama, A., and Amano, F. (2017). Induction of viable but nonculturable Salmonella in Exponentially grown cells by exposure to a low-humidity environment and their resuscitation by catalase. J. Food Prot. 80, 288-294. doi: 10.4315/0362-028x.jfp-16-183

Oliver, J. D., Dagher, M., and Linden, K. (2005). Induction of Escherichia coli and Salmonella typhimurium into the viable but nonculturable state following chlorination of wastewater. J. Water Health. 3, 249-257. doi: 10.2166/wh.2005.040

Pu, Y., Li, Y., Jin, X., Tian, T., Ma, Q., Zhao, Z., et al. (2019). Dependent dynamic protein aggregation regulates bacterial dormancy depth critical for antibiotic tolerance. Mol. Cell. 73:e4.

Purevdorj-Gage, L., Nixon, B., Bodine, K., Xu, Q., and Doerrler, W. T. (2018). Differential effect of food sanitizers on formation of viable but nonculturable Salmonella enterica in poultry. J. Food Protect. 81, 386-393. doi: 10.4315/0362028x.jfp-17-335

Robben, C., Fister, S., Witte, A. K., Schoder, D., Rossmanith, P., and Mester, P. (2018). Induction of the viable but non-culturable state in bacterial pathogens by household cleaners and inorganic salts. Sci. Rep. 8:15132.

Roszak, D. B., Grimes, D. J., and Colwell, R. R. (1984). Viable but nonrecoverable stage of Salmonella enteritidis in aquatic systems. Can. J. Microbiol. 30, 334-338. doi: 10.1139/m84-049

Sharma, J., Kumar, D., Hussain, S., Pathak, A., Shukla, M., Prasanna Kumar, V., et al. (2019). Prevalence, antimicrobial resistance and virulence genes characterization of nontyphoidal Salmonella isolated from retail chicken meat shops in Northern India. Food Control. 102, 104-111. doi: 10.1016/j.foodcont. 2019.01.021

Wang, L., Zhao, X., Chu, J., Li, Y., Li, Y., Li, C., et al. (2011). Application of an improved loop-mediated isothermal amplification detection of Vibrio parahaemolyticus from various seafood samples. Afr. J. Microbiol. Res. 5, 5765-5771. doi: 10.5897/AJMR11.1237

Wang, X., Xu, X., Hu, W., Zuo, K., Kan, Y., Yao, L., et al. (2019). Visual detection of porcine epidemic diarrhea virus using a novel reverse transcription polymerase spiral reaction method. BMC Vet Res. 15:116. doi: 10.1186/s12917-019-1851-7

Wen, S., Feng, D., Chen, D., Yang, L., and Xu, Z. (2020). Molecular epidemiology and evolution of Haemophilus influenzae. Infect. Genet. Evol. 80:104205. doi: 10.1016/j.meegid.2020.104205

Xie, J., Peters, B. M., Li, B., Lin, L., Yu, G., Xu, Z., et al. (2017a). Clinical features and antimicrobial resistance profiles of important Enterobacteriaceae pathogens in guangzhou representative of Southern China, 2001-2015. Microb. Pathog. 107, 206-211. doi: 10.1016/j.micpath.2017.03.038

Xie, J., Yang, L., Peters, B. M., Chen, L., Chen, D., Li, B., et al. (2017b). A 16-year retrospective surveillance report on the pathogenic features and antimicrobial susceptibility of Pseudomonas aeruginosa isolated from Guangzhou representative of Southern China. Microb. Pathog. 110, 37-41. doi: 10.1016/j.micpath.2017.06.018

Xu, Z., Gui, Z., Lin, L., Li, B., Su, J., Zhao, X., et al. (2012a). Expression and purification of gp41-gp36 Fusion protein and application in serological screening assay of HIV-1 and HIV-2. Afr. J. Microbiol. Res. 6, 6295-6299. doi: 10.5897/AJMR12.1075

Xu, Z., Hou, Y., Peters, B. M., Chen, D., Li, B., and Li, L. (2016a). Chromogenic media for MRSA diagnostics. Mol. Biol. Rep. 43, 1205-1212. doi: 10.1007/ s11033-016-4062-3

Xu, Z., Hou, Y., Qin, D., Liu, X., Li, B., Li, L., et al. (2016b). Evaluation of current methodologies for rapid identification of methicillin-resistant staphylococcus aureus strains. Basic Clin. Pharmacol. Toxicol. 118:33.

Xu, Z., Li, L., Alam, M. J., Zhang, L., Yamasaki, S., and Shi, L. (2008a). First confirmation of integron-bearing methicillin-resistant Staphylococcus aureus. Curr. Microbiol. 57, 264-268. doi: 10.1007/s00284-008-9187-8

Xu, Z., Li, L., Shi, L., and Shirtliff, M. E. (2011a). Class 1 integron in staphylococci. Mol. Biol. Rep. 38, 5261-5279. doi: 10.1007/s11033-011-0676-7

Xu, Z., Li, L., Shirtliff, M. E., Alam, M. J., Yamasaki, S., and Shi, L. (2009). Occurrence and characteristics of class 1 and 2 integrons in Pseudomonas aeruginosa isolates from patients in Southern China. J. Clin. Microbiol. 47, 230-234. doi: 10.1128/JCM.02027-08

Xu, Z., Li, L., Shirtliff, M. E., Peters, B. M., Peng, Y., Alam, M. J., et al. (2010). First report of class 2 integron in clinical Enterococcus faecalis and class 1 integron in Enterococcus faecium in South China. Diagn. Microbiol. Infect. Dis. 68, 315-317. doi: 10.1016/j.diagmicrobio.2010.05.014

Xu, Z., Li, L., Zhao, X., Chu, J., Li, B., Shi, L., et al. (2011b). Development and application of a novel multiplex polymerase chain reaction (PCR) assay for 
rapid detection of various types of staphylococci strains. Afr. J. Microbiol. Res. 5, 1869-1873. doi: 10.5897/AJMR11.437

Xu, Z., Liang, Y., Lin, S., Chen, D., Li, B., Lin, L., et al. (2016c). Crystal Violet and XTT Assays on Staphylococcus aureus Biofilm Quantification. Curr. Microbiol. 73, 474-482. doi: 10.1007/s00284-016-1081-1

Xu, Z., Lin, L., Chu, J., Peters, B. M., Megan, M., Harris, L., et al. (2012b). Development and application of loop-mediated isothermal amplification assays on rapid detection of various types of staphylococci strains. Food Res. Int. 47, 166-173. doi: 10.1016/j.foodres.2011.04.042

Xu, Z., Lin, L., Shirtliff, M. E., Peters, B. M., Li, B., Peng, Y., et al. (2011c). Resistance class 1 integron in clinical methicillin-resistant Staphylococcus aureus strains in southern China, 2001-2006. Clin. Microbiol. Infect. 17, 714-718. doi: 10.1111/j. 1469-0691.2010.03379.x

Xu, Z., Shi, L., Alam, M. J., Li, L., and Yamasaki, S. (2008b). Integron-bearing methicillin-resistant coagulase-negative staphylococci in South China, 20012004. FEMS Microbiol. Lett. 278, 223-230. doi: 10.1111/j.1574-6968.2007. 00994.x

Xu, Z., Shi, L., Zhang, C., Zhang, L., Li, X., Cao, Y., et al. (2007). Nosocomial infection caused by class 1 integron-carrying Staphylococcus aureus in a hospital in South China. Clin. Microbiol. Infecti. 13, 980-984. doi: 10.1111/j.1469-0691. 2007.01782.x

Xu, Z., Xie, J., Peters, B. M., Li, B., Li, L., Yu, G., et al. (2017a). Longitudinal surveillance on antibiogram of important gram-positive pathogens in Southern China, 2001 to 2015. Microb. Pathog. 103, 80-86. doi: 10.1016/j.micpath.2016. 11.013

Xu, Z., Xie, J., Yang, L., Chen, D., Peters, B. M., and Shirtliff, M. E. (2018). Complete Sequence of pCY-CTX, a Plasmid Carrying a Phage-Like Region and ISEcp1Mediated Tn2 Element from Enterobacter cloacae. Microb. Drug Resist. 24, 307-313. doi: 10.1089/mdr.2017.0146

Xu, Z., Xu, X., Yang, L., Li, B., Lin, L., Li, X., et al. (2017b). Effect of aminoglycosides on the pathogenic characteristics of microbiology. Microb. Pathog. 113, 357364. doi: 10.1016/j.micpath.2017.08.053
You, R., Gui, Z., Xu, Z., Shirtliff, M. E., Yu, G., Zhao, X., et al. (2012). Methicillinresistance Staphylococcus aureus detection by an improved rapid PCR assay. Afr. J. Microbiol. Res. 6, 7131-7133. doi: 10.5897/AJMR12.708

Zeng, B., Zhao, G., Cao, X., Yang, Z., Wang, C., and Hou, L. (2013). Formation and resuscitation of viable but NonculturableSalmonella typhi. BioMed Res. Int. 2013, 1-7. doi: 10.1155/2013/90 7170

Zhang, N., Gui, Z., Li, X., Huang, J., Hu, K., Gao, Y., et al. (2013). Solvent-free enzymatic synthesis of 1, 3-Diacylglycerols by direct esterification of glycerol with saturated fatty acids. Lipids $n$ Health nd Dis. 12, 2-7. doi: 10.1186/1476511X-12-65

Zhao, X., Li, M., and Xu, Z. (2018a). Detection of foodborne pathogens by surface enhanced raman spectroscopy. Front. Microbiol. 9:1236. doi: 10.3389/fmicb. 2018.01236

Zhao, X., Yu, Z., and Xu, Z. (2018b). Study the features of 57 confirmed CRISPR Loci in 38 Strains of Staphylococcus aureus. Front. Microbiol. 9:1591. doi: 10. 3389/fmicb.2018.01591

Conflict of Interest: YL was employed by the company Guangdong Zhongqing Font Biochemical Science and Technology Co. Ltd.

The remaining authors declare that the research was conducted in the absence of any commercial or financial relationships that could be construed as a potential conflict of interest.

Copyright (c) 2020 Li, Huang, Bai, Fu, Chen, Liang, Wang, Liu, Gong and Liu. This is an open-access article distributed under the terms of the Creative Commons Attribution License (CC BY). The use, distribution or reproduction in other forums is permitted, provided the original author(s) and the copyright owner(s) are credited and that the original publication in this journal is cited, in accordance with accepted academic practice. No use, distribution or reproduction is permitted which does not comply with these terms. 